\title{
Breve navegação de uma gata de jade
}

Short sailing of a jade cat

Mestrando em Teoria da Literatura no Programa de Pós-Graduação em Letras da Pontifícia Universidade Católica do Rio Grande do Sul, bolsista CNPq.

(17) https://orcid.org/0000-0003-4667-8186 E-mail: luis.alberto@acad.pucrs.br
Sei que há léguas a nos separar Tanto mar, tanto mar Sei, também, que é preciso, pá \author{
Navegar, navegar \\ (Chico Buarque)
}

RESUMO: 0 presente trabalho tem por objetivo analisar o romance Requiem para o navegador solitário, de Luís Cardoso, a fim de se observar a constituição metafórica da figura do navegador. Realiza-se uma breve retrospectiva da imagem das navegações para o cenário lusófono - sobretudo aventurar-se por Díli em busca de seu príncipe encantado e de um encontro finalmente íntimo consigo própria.

Palavras-chave: Navegação; Literatura timorense; Viagem.

A constitution of the figure of the navigator. When a very brief retrospective of the image of navigations to the world scene is made - especially for War, is also evaluated in this research. From the imaginary point of view, the reading of the journey as an attitude of liberation is revisited in the transposition of the primordial locus of action to a female, young, Eastern character, forced (and instigated by herself) to venture into Dili in the

Keywords: Navigation; Timorese literature; Trave. 
A casa em que um homem vive é um prolongamento deste. Descrevê-la é descrever o seu ocupante. (Wellek \& Warren)

Madalena já havia dado conta de que eu ficava ali várias vezes na varanda a olhar para o mar, para a linha do horizonte

ou para nada. Talvez em busca de algo para onde dirigisse a minha atenção, uma gaivota, um veleiro ou simplesmente nada. Absolutamente nada a não ser o mar, uma extensão enorme de água lisa sem uma falha ou uma ruga que prendesse minha atenção.

Vagueava para além da linha que separa

o mar do céu e entrava num deserto de nuvens brancas. Tudo parecia igual desde sempre.

(Catarina, Luís Cardoso)

Navigare necesse; vivere non est necesse.

(Pompeu)

\section{Introdução: as muitas navegações}

A expansão marítima e a conquista de grande parte do território global - são feitos históricos que muito orgulham as grandes nações a partir do século XIV. Portugal, um dos maiores ícones das "descobertas" de novas terras, foi responsável por colonizar diversos terrenos ao redor do planeta, construindo um império como poucas vezes visto no decurso da história mundial. Dentre as motivações para essas grandes incursões, estava a necessidade de encontrar novos meios de produção. As especiarias, por exemplo, estavam sob o monopólio dos italianos - que taxavam os produtos com valores altos. Sobre essa renovadora empreitada, Diego Pimentel de Souza Dutra, em A cultura dos descobrimentos em Portugal: um estudo da relação entre a Sabedoria do Mar e o Conhecimento Acadêmico na Renascença (2013), diz que

Embora fosse uma obra conjunta de portugueses e espanhóis, sendo o fenômeno sociocultural mais significativo gerado no e pelo Renascimento português, tal processo não se limitou à Península Ibérica, correspondendo, na realidade, a um feito comum de uma Europa em processo de expansão, à conquista do mundo (DUTRA, 2013, p.46).

Dutra ressalta ainda que "a Expansão Ultramarina e o Renascimento devem ser vistos como fenômenos interligados, na medida em que estão inseridos em um mesmo contexto histórico de transformações sociais" (DUTRA, 2013, p.47). Mas o mito do grande navegador é anterior a todas essas necessidades. Sob a figura de majestosos heróis, a cultura grega é recheada de figuras lendárias: Hércules, Ulisses, Perseu, Aquiles, dentre tantos outros. $\mathrm{O}$ que há de comum nessas personagens é a coragem e as aventuras por elas vividas. Muitos séculos mais tarde, por volta dos anos 1400, em Portugal, o infante D. Henrique seria responsável por consolidar a renovação do mito desses grandes homens que almejam novas terras. Um dos exemplos mais conhecidos é o de Vasco da Gama, que partiu de Lisboa por rota marítima e descobriu o caminho para o Oriente. Tal fato é ficcionalizado, por exemplo, em Os Lusíadas, de Luís de Camões.

O navegador, porém, na realidade, não possuía poderes especiais. Tampouco é improvável que fosse abençoado por deuses, que o conduziam à glória. No entanto, também não era qualquer indivíduo que podia tornarse um navegador. Era preciso dominar a tecnologia emergente, além de ser capaz de dominar as noções de navegação marítima, leitura de cartografias, dentre outras habilidades. Segundo Fábio Pestana Ramos, em $O$ apogeu e declínio do ciclo das especiarias: uma análise comparativa das navegações 
portuguesas da Carreira da Índia e da Carreira do Brasil (2002), no processo seletivo para os navegadores

Exigia-se dos capitães das embarcações portuguesas que fossem 'oficiais de carreira', visando comandarem as 'manobras de marinhagem', e que 'de preferência' pertencessem à 'classe nobre, isto para se imporem pela sua condição' aos 'marinheiros de má índole, sempre prontos a insubordinar-se' (RAMOS, 2002, p.170).

Mas para se pensar na história das navegações e em suas consequências no âmbito global, é preciso ir além. Há de se levar em conta o choque entre culturas quando os portugueses chegam à Índia, por exemplo. A relação, como se pode imaginar, não é totalmente pacífica, e também o estabelecimento de uma nova onda comercial não se dá de maneira natural. Conforme Ramos (2002),

A despeito da tolerância cultural esperada por parte de um povo eclético, isto dado a própria formação de seu país, quando os portugueses chegaram à Índia só conseguiam enxergar potenciais cristãos ou infiéis, demonstrando uma total falta de percepção quanto às diferenças civilizacionais, mostrando serem incapazes de enxergar o outro, embora, ao contrário do que ocorreu na África, julgassem os indianos até certo ponto como homens civilizados (RAMOS, 2002, p. 402).

Por isso, ao se pensar nesse movimento de lançar-se ao mar, é imprescindível refletir sobre a figura do navegador e de seu impulso ao horizonte. Segundo Sergio Cardoso, em O olhar viajante do etnólogo (1988):

A viagem, então, como o olhar, [...] temporaliza a realidade reempreendendo a busca de seu sentido. Assim, manifesta-se nela a abertura ou indeterminação do mundo e, nesta, [...] o escoamento inesgotável do tempo (CARDOSO, 1988, p. 349).

O pioneirismo português permitiu a cartografia de um mundo, que se constituía parcialmente pelo "novo", pelo que poderia vir a ser "descoberto". Bem se sabe, no entanto, que neste movimento de descoberta e reconhecimento de geografias, pessoas, costumes e crenças, o navegador tornava-se, também, um outro "redescoberto". A partir daí, as inúmeras camadas que envolvem o indivíduo mostravam-se multiplicáveis e imprevisíveis. Segundo Octávio Ianni, em A metáfora da viagem (2000): “No curso da viagem há sempre alguma transfiguração, de tal modo que aquele que parte não é nunca o mesmo que regressa" (IANNI, 2000, p.31).

As viagens tiveram decisiva importância durante as grandes guerras que assolaram o mundo. As nações, imbuídas de força de ataque e estratégias constantes, utilizaram-se das grandes navegações como forma de tomar a dianteira em muitos dos conflitos.

Na literatura, a imagem do navegador, isto é, do homem desbravador lançado ao mar num impulso muitas vezes abençoado pelos deuses não é nova. Desde os clássicos mitos gregos como Ulisses, ou na literatura lusófona, passando por Os Lusíadas e mesmo na Carta de Pero Vaz de Caminha, a importância dos deslocamentos ultramarinos é evidente. Como consequência desses movimentos, o mar tornou-se um símbolo incutido no imaginário popular: em diversas manifestações artísticas, e em seus mais variados gêneros, o signo do mar tem guardado mistérios que têm permitido renovações constantes nos mais diversos campos, ora nas artes plásticas, ora em produções cinematográficas hollywoodianas e mesmo na literatura. Segundo Conceição Flores, em Viagem à ilha (des)conhecida ${ }^{1}$ (2013)

O tema dos oceanos foi abordado sob diversas perspectivas, entre elas a da inspiração artística que o mar tem sido para poetas e escritores. Assim, alguns escritores foram convidados a escrever sobre essa temática, entre eles, Saramago. Desse convite resultou $O$ conto da ilha desconhecida, de José Saramago (FLORES, 2013, p. 31).

0 texto integra a coletânea Travessias pela literatura portuguesa estudos críticos de Saramago a Vieira organizada por Aldinida Medeiros. 
No contexto literário brasileiro, há, por exemplo, Canaã, de Graça Aranha, já representando os processos imigratórios. E é possível notar que o imaginário brasileiro influenciado pelo signo do mar é ainda maior: o poeta João Cabral de Melo Neto, por exemplo, desenvolveu, com seus eu-líricos, diversas reflexões a respeito da temática marítima, como em "Paisagens com cupim", da obra Quaderna ${ }^{2}$ (1959); Lúcio Cardoso, autor nascido nas Minas Gerais e que escreveu contos, romances, novelas e poesia também evoca, em diversos momentos, o símbolo do mar; Hilda Hilst, em Do desejo (e em outras obras) também evoca as águas; ainda no campo do gênero da poesia lírica, Cecília Meireles utiliza a água como símbolo plurissignificativo, em Viagem; ao se tratar das narrativas brasileiras, pode-se elencar Mar morto, de Jorge Amado, Memorial de Aires, de Machado de Assis, Enquanto água, de Altair Martins, Cais saudade em pedra, de Moacir Costa Lopes e tantos outros.

No cenário da narrativa mundial, há também diversas obras que exploram o campo semântico das águas misteriosas: Moby Dick, de Herman Melville, Robinson Crusoé, de Daniel Defoe, $O$ velho e o mar, de Ernest Hemingway, Mensagem, de Fernando Pessoa e incontáveis outras obras ao redor do mundo. Para a elaboração deste trabalho, o romance de Luís Cardoso, Requiem para o navegador solitário (2006) será o ponto central.

Luís Cardoso de Noronha é um dos mais importantes escritores timorenses. Nascido em 1958, é natural de Cailaco, e tanto seu pai quanto sua mãe são de origem étnica calade. A língua materna do pai é o mambai, falada principalmente pelos habitantes do interior até a costa sul de Díli; sua mãe é falante de lacló, um dialeto do galóli que, embora não desfrute do título de língua oficial do Timor Leste (atribuído ao português e ao tétum), é falada por grande parte da população do litoral norte do município de

2 O excerto foi retirado da edição Obra completa, de 1994, da editora Nova Aguilar.
Manatuto - essa diversidade linguística que vem de casa pode ser observada em algumas de suas obras: o tétum, por exemplo, tem forte presença no romance Crônica de uma travessia, de 1997. Luís Cardoso desempenhou as funções de Representante do Conselho Nacional da Resistência Maubere em Portugal, foi cronista da revista Fórum Estudante e professor de Tétum e Língua Portuguesa nos cursos de formação especial para timorenses. Segundo Claudiany Pereira, em Luís Cardoso e a vivência da diáspora: nota sobre a literatura de Timor Leste (2006)

O pioneirismo de Luís Cardoso - que é prosador, porém não o único, num universo marcado pela poesia -, autor de Crônica de uma travessia, Olhos de coruja, Olhos de gato bravo e A última morte do Coronel Santiago, além de contos publicados em antologias, tais como Antes da Meia-Noite e Vésperas de Natal, ambas da Editora Dom Quixote, merece ser constantemente enfatizado, por representar um espaço sociocultural complexo como o de Timor Leste (PEREIRA, 2006, p.38).

Ainda segundo Micaela Ramon, em Contributos para a constituição de um cânone lusófono: Timor-Leste no contexto da produção literária em língua portuguesa (2014), embora Luís Cardoso seja "considerado o mais representativo autor timorense da atualidade",

a sua obra não é ainda suficientemente conhecida e valorizada, nem em Portugal, país onde é editado, nem nos restantes países lusófonos, nem mesmo em Timor onde são escassos os que têm acesso aos bens culturais e capacidade para os fruir e apreciar. Cremos, no entanto, ser do interesse de todos - do autor, dos timorenses e da vasta comunidade de falantes do português - que a sua obra passe a integrar o cânone lusófono (RAMON, 2014, p. 68).

Segundo a leitura de Pedro Gabriel Reis Albuquerque, em sua dissertação intitulada Caleidoscópio literário: a representação romanesca em Luís Cardoso (2014), 
Cardoso imbui a narrativa com acontecimentos e atores em estreita ligação com a História de Timor. Para além da envolvência histórica, são transversais, na sua encenação romanesca, os diálogos entre tempos, entre romances e entre vozes cuja matriz comum, e elo, é a cultura timorense. Ao transpor elementos da cultura e da vivência nativa para o espaço literário, Cardoso contribui para a construção da identidade e da memória coletiva timorense (ALBUQUERQUE, 2014, p.5).

Sobre Requiem para o navegador solitário, Damares Barbosa diz que

o romance) é narrado em primeira pessoa, sob o olhar feminino (de Catarina), que ao longo dos 16 capítulos observa e relata os acontecimentos internos vivenciados em Timor Leste, mesclados à política imposta pelo governo salazarista, às suas colônias. Ao mesmo tempo romântico e contundente, o livro de Luís Cardoso descreve a travessia realizada pelas mulheres em Timor, no período entre guerras, denunciando as atrocidades cometidas pelos japoneses, aliados e, também, o dano causado pela falta do efetivo cumprimento por parte das autoridades portuguesas (BARBOSA, 2010, s/n).

Localizado temporalmente no período do comando salazarista em Portugal, Requiem mostra a situação de "neutralidade" que o Timor representa em contraste à ameaça nipônica ao território, enquanto australianos e holandeses solicitam a possibilidade de "defender" o povo timorense da mescla da população local com os japoneses, que beneficiava estes. Catarina é filha de um comerciante chinês e fica noiva de um navegador português capitão do porto de Díli. Porém, com a decadência do comércio em Batávia (Indonésia), o pai de Catarina a manda para o Timor, atrás do noivo, a fim de garantir o investimento no negócio local. A relação com o noivo não é nada próxima aos sonhos de Catarina. Pelo contrário! Em certa altura do romance, ela compreende que o hábito de entregarem gatos às mulheres é um símbolo de interesse por algo em troca - além de tal gesto ser feito às amantes, visto que às esposas davam-se chocolates e rosas. Aos poucos, os capitães e demais figuras políticas de Díli vão interagindo com Catarina, que interfere diretamente na ordem daquela sociedade. Em dado momento, a personagem reflete:

Aos dezessete anos, muito cedo na minha vida, comecei a tratar de gatos. Coisa que só as idosas fazem quando chega a altura em que a serenidade lhes permite que abandonem tudo para se dedicarem a contemplar a queda das folhas, ou a luz que as atravessa, com o mesmo encantamento dos tempos de infância (CARDOSO ${ }^{3}, 2006$, p. 41).

A temática das relações políticas entre colônia e metrópole, bem como o tema das travessias não se reduz ao romance aqui analisado. Conforme Vicente Paulino e Mariene de Fátima Cordeio Queiroga, em A memória da infância e a formação da nação emergente em Luís Cardoso (2017),

Luís Cardoso coloca sempre a história de Timor nos seus três romances, como a fase inicial da construção textual, criticando o colonialismo, sobretudo a política desonrada da Indonésia, expressando a história mais ampla de um mundo e de um sujeito no tempo presente e descontínuo, o tempo do trânsito, do reconhecimento das diferenças, do passado e do presente, da migração pós-colonial, a história do estar no exílio, em terra que não é sua, mas de todos os exilados e por motivo do seu estudo no exílio, o narrador não presenciava fisicamente na guerra civil e na posterior invasão Indonésia (PAULINO; QUEIROGA, 2017, p. 274).

Faz-se importante lembrar que Luís Cardoso vive em Portugal, o que se configura como uma vivência de diáspora: daí a importância da relação entre o local de fala, no caso a metrópole colonizadora, em relação ao local de origem, que também é a gênese de seu projeto literária, a colônia Timor. Como salienta Letícia Villela Lima da Costa, em Metáforas do mosaico: Timor Leste em Ruy Cinatti e Luis Cardoso (2012),

3 Todas as citações presentes nesse texto são extraídas dessa mesma edição. 
Escrever na diáspora é uma experiência bastante singular. Não podemos negar que o distanciamento é algo que influencia muito a escrita, mas muitas vezes, é algo extremamente necessário. A distância, o estar fora de algum lugar, pode trazer uma lucidez maior acerca dos fatos e, consequentemente, nos permite trabalhar a memória de forma mais apurada. Quando estamos longe do nosso lugar de origem, como é o caso na diáspora, estamos sujeitos a outras influências, que podem nos proporcionar outras abordagens, outras visões dos acontecimentos (COSTA, 2012, p. 137)

Ao propiciar a reflexão acerca da figura do navegador e dos processos políticos que envolvem as navegações, o romance de Luís Cardoso será analisado com o objetivo de observar a representação desse papel de "homem do mar" e as implicações sociais que dele decorrem. Para evidenciar tal olhar, o protagonismo de Catarina será minuciosamente observado, visto que é dela que partem os desejos de se relacionar com um príncipe que, a essa altura, só poderia ser de além-mar. Somado a isso, ao atentar-se para o contexto histórico-social que antecede a Segunda Guerra Mundial e as relações de poder e de influência que envolve a colônia e o colonizador, este trabalho visa à identificação dos recursos utilizados na constituição de uma possibilidade de ser Portugal e Timor.

\section{A liturgia dos mares: uma navegadora ilhada}

A viagem nos ensina algumas coisas. Que a vida é o caminho e não o ponto fixo no espaço. Que nós somos feito a passagem dos dias e dos meses e dos anos, como escreveu o poeta japonês Matsuo Bashô num diário de viagem, e aquilo que possuímos de fato, nosso único bem, é a capacidade de locomoção. É o talento para viajar (LISBOA, 2007, p. 125).

Catarina é uma ilha presa a uma ilha. Embora tenha sido enviada para Díli, reconhece que seu destino era cruzar os horizontes. Partir em viagem foi, para ela, sair das nuvens de seus sonhos e começar a viver. Não podia mais continuar a crer numa ideia de príncipe que jamais chegaria. Quando Alberto Sacramento Monteiro escolheu a ela - e não a gata de jade que iluminava a sala de casa, símbolo de sucesso - seu destino estava para além-mar. Contudo, se, por um lado, a ida de Catarina para o Timor vingava o desejo pessoal de seu pai, ao mesmo tempo em que concretizava seus sonhos, a traumática experiência (sobretudo sexual) com o capitão do porto a fez desacreditar de quase tudo, exceto de seu príncipe porvir:

Há muito tempo que esperava, nessa mesma varanda atapetada de buganvílias, por alguém que viesse de longe para me resgatar. Um desses heróis de contos de fada, depois de ter vencido os monstros que lhe dificultavam a passagem. É nos mitos de infância que vamos resgatar as nossas referências quando a realidade nos atormenta (CARDOSO, 2006, p. 173).

Alberto não fora o cavaleiro charmoso com que Catarina tanto sonhara. Suas estradas eram aquosas e seus objetivos mesquinhamente vagos. Sorrateiro, condescendente e pouco amistoso, o capitão do porto precisava desaparecer para que a narrativa - e Catarina - prosseguissem. Símbolo fácil de um sedutor embrutecido por águas duras, Alberto foi o gatilho de que Catarina necessitava para cruzar o oceano e chegar à casa no litoral do Timor. Diferente de Alberto, o Abissínio, "de cor fulva e grandes olhos de âmbar", Alberto, o navegador, não ficou tão surpreendido com as qualidades da jovem: "saber línguas estrangeiras, ler os clássicos, tocar piano e admirar Debussy" foi uma extravagância pouco relevante para competir com o comércio marítimo e as obrigações de um homem de negócios.

Entretanto, o sonho de Catarina, conforme assinalado anteriormente, não morreu assim tão facilmente. De acordo com Maffesoli (2001): 
O mito do cavaleiro errante, quaisquer que sejam as figuras contemporâneas que possa assumir, continua presente no imaginário coletivo. No próprio quadro das sociedades industriais a pulsão da viagem, a busca do sol está longe de ser marginal. São também modulações da procura do Graal (MAFFESOLI, 2001, p. 40)

Importante construção realizada no romance de Luís Cardoso, as personagens femininas ganham destaque na sociedade timorense: embora Catarina seja estrangeira e vista como prostituta ou traidora (em favor dos nipônicos), sua inserção naquele espaço inóspito sofre, gradativamente, diferenças substanciais. É com ajuda de Madalena que Catarina ganha força na narrativa. Em parte, a relação entre as duas já nasce com um vínculo solidamente perturbador: ambas possuem filho de Alberto Monteiro: Madalena dá à luz fruto de uma relação hostil e indesejada, Diogo; Madalena tem Esmeralda. Em tempos distintos, ambas são vítimas de uma ideia do navegador que não corresponde à realidade. Segundo Catarina:

0 destino de uma mulher é uma caixa de Pandora. Nunca se sabe o que tem dentro. A sorte pode ditar um príncipe encantado. Nem sempre o desejado. Apaixonar-se por um marinheiro pode ser uma aventura sem retorno, como quando se entra pelo mar, quando as tempestades recomendam que se fique em terra. Sujeita-se a ser largada ao primeiro toque de rebate. Depois deambula à espera de ser resgatada por um coração de manteiga. Que o têm também os marinheiros solitários, viajantes em busca de outros ares, caçadores de fortunas, olheiros de mundos mágicos [...] (CARDOSO, 2006, p. 12-13).

De acordo com Carlos Henrique Lucas Lima, em A questão transcontinental em Requiem para o navegador solitário (2012),

A literatura de Cardoso oferece esse modelo teórico multicultural preocupado com a visibilização das diferenças, inclusive apostando na condução da diegese por parte de uma narradora mulher. Ao inserir no centro da narrativa a voz feminina, e ainda ao ter como foco diegético quase que exclusivamente Catarina, orienta a leitura do romance no sentido do multiculturalismo que aqui chamamos "da diferença" (LIMA, 2012, p. 8).
Se, num primeiro momento, ela é uma peça desencaixada do jogo político timorense, sua vida sofre uma guinada ao se encontrar com o líder de Manumera4 ${ }^{4}$ Al-Mu'tamid, Malisera. E é Lavadinho o representante do poder salazarista na ilha que trata de ficar na sombra de Catarina, investigando sua relação com o rebelde procurado. Este homem, que sempre usa luvas brancas e que pode causar qualquer horror sem deixar vestígios ("isso é coisa do Lavadinho") - com a ajuda de Hermínio, o encoberto - tem total liberdade para explorar a formação das guerrilhas no Timor, a partir do estouro da Segunda Grande Guerra.

E no meio desta jornada, é Madalena que serve como braço direito de Catarina: não só cuidando de Nina, a Névoa, Alberto, o Abissínio, Geraldo, o Birmanês, César, o Balinês, Diogo, o Turco-Otomano, Félix, o Maremoto ou o imaginado Alain, o Bora Bora, mas também servindo como apoio em seus devaneios, mesmo enquanto espera o retorno do noivo Pedro, o Porteiro, e seus parceiros João, o Iluminado e Tomé, o Desconfiado, ela revitaliza a fé de Catarina e a apoia em suas aventuras e sonhos:

Madalena entrou naquela casa como uma lufada de ar fresco (...) nos primeiros tempos dedicava-me a observá-la. Era uma mulher frágil mas ao mesmo tempo decidida (...) parecia disposta a sair de um qualquer desaire com a mesma determinação com que um dia se fez ao mar, na esperança de recuperar o noivo (CARDOSO, 2006, p. 45)

Além dele, há outras figuras que rondam o cenário timorense e que influenciam constantemente na vida de Catarina: Rodolfo Marques da Costa, natural do Algarve, é exilado no Timor após ser expulso do Brasil por ter realizado um atentado, em nome da Legião Vermelha, contra o hotel Francforte, do Rossio, e agora vive no Hotel Salazar; Indian Jones, figura soturna que recebera o apelido do famoso aventureiro por representar uma

${ }^{4}$ Município de Timor Leste. 
mão-de-obra violenta de poucas perguntas, fica obcecado por Catarina; Antero Quadro Escuro canta a vida timorense, seus mistérios e fofocas através de poemas - que se tornam cantatas - que ecoam pelos quatro cantos de Díli; e Sir Lawrence, figura que ronda o trágico e o cômico, conforme pode-se observar no excerto abaixo:

0 anfitrião (Sir Lawrence) pedia silêncio (...) entoava de pé e emocionado God save the King, com um sotaque que foi aprimorado ao longo do tempo ouvindo a BBC, ao ponte de ter sido referenciado pelos visitantes da ilha como o manual de bem se exprimir na língua da mãe pátria. Tal confusão de pertenças valeu-lhe numa dessas ocasiões uma reprimenda das autoridades portuguesas, irritadas com a sua mania das grandezas, para que se servisse apenas da língua do país em cujo território encontrara abrigo e fizera fortuna através dos seus contactos com os estrangeiros (CARDOSO, 2006, p. 22).

Segundo Priscilla de Oliveira Ferreira, em sua tese Que Timor é este na literatura de Luís Cardoso?, "seus personagens, na maioria, assinalaram a cultura do colonizar, aprenderam o seu idioma e receberam uma educação ocidental" (FERREIRA, 2014, p.215). É o caso de Catarina, que é leitora fiel de $A$ la poursuite du Soleil, de Alain Gerbault (personagem ficcionalizado e introduzido no final da narrativa como o navegador solitário que chega numa jangada, vindo da França, ao Timor). Ela passa a perceber que sua vida depende de um emaranhado de peças políticas que iniciam um movimento com o objetivo de encurralá-la e encontrar sua culpa na relação com Malisera. Com posicionamentos surpreendentes e enérgicos, ela passa a confrontar o estado atual e impõe uma nova forma de ser compreendida pelos habitantes:

Surpreendi-o quando lhe disse por que razão me deslocava a Manumera. Era a aventura que me levava ali, da mesma forma que quando decidira assumir todos os riscos viajando para Timor (...) não me sentia arrependida de ter feito a viagem. Na vida, nem sempre o que pensamos encontrar se ajusta aos nossos propósitos. Mas o que importava mesmo era seguir em frente (CARDOSO, 2006, p. 56).
Em consonância a tal atitude, o sequestro de seu filho e a chegada de um novo capitão ao porto estremece as convicções de todos. É perceptível que a relação do homem com o mar é mais do que uma escolha de profissão. É, também, uma tomada de destino. Mas não seria apenas isso. Para Catarina, a vida nas águas é uma decisão de autoflagelo. Assim como o amor pode ser punitivo e autodestrutivo, o mar é um lençol estendido para receber os visitantes que necessitam de um longo sonho, sem retorno. Em uma das diversas análises realizadas por Madalena a respeito da vida de um navegador, ela enuncia:

$\mathrm{Na}$ altura julgava que ser marinheiro, mais do que uma profissão, tinha algo a ver com a aventura e com o gosto pelas viagens e provações. Ninguém se atirava assim para o mar como se fosse para uma padaria cozer pão (CARDOSO, 2006, p. 91).

E reitera dizendo que "na altura julgava que ser marinheiro, mais do que uma profissão, tinha algo a ver com a aventura e com o gosto pelas viagens e provações" (CARDOSO, 2006, p.91). Essa capacidade de se deslocar, sem a pretensão de fixar-se num solo é objeto de análise por diversos campos de estudo nas ciências humanas. Segundo Claudio Almeida, em Representações do deslocamento no texto literário (2011):

A presença de identidades fragmentadas, de sujeitos desenraizados, de pertencimentos esmaecidos participa decisivamente da problematização de questões significativas de um certo homem contemporâneo, tais como a revisão de fronteiras geográficas, as motivações dos deslocamentos humanos, as estratégias de reconhecimento e contato com a alteridade, as conexões entre espaços e indivíduos (ALMEIDA, 2011, p.113).

A crença em um ser que viria a resgatar e propiciar-lhe grande felicidade numa relação saudável não cessa de existir em Catarina. Mesmo após grandes desilusões e desapontamentos, continua a lançar seu olhar ao 
horizonte na tentativa de pescar um novo sonho, um novo modo de existir. É perceptível que a relação da personagem com o tempo é conduzida de forma natural: os fatos cronologicamente narrados desenvolvem-se com passagens curtas de tempo, alimentando aspectos político-sociais evidentes desde a chegada da personagem ao Timor. Esse modo de ser, em um otimismo quase bucólico, a torna uma personagem forte, mas revestida de uma sensibilidade pueril. Catarina continuava a deixar o petromax aceso, todas as noites:

(...) achava que era uma loucura esperar por um aventureiro, ainda por cima viajando sozinho no encalço do sol, sujeitando-se às intempéries e aos assaltos dos piratas. Nunca iria procurar abrigo numa ilha como Timor, que embora fosse conhecida como a terra onde nascia o sol, era antes o local para onde mandavam aqueles coitados que os outros rejeitavam, para serem esquecidos ou para morrerem de longe da pátria, da família e de Deus (CARDOSO, 2006, p. 86).

Concomitante aos desejos íntimos de Catarina cresce também o clima de perigo iminente frente às relações diplomáticas (ou a falta delas). E no centro dessa crise está a condição estrategicamente neutra de Portugal. Conforme Ferreira (2014),

Muitos personagens dos romances de Luís Cardoso apresentam um forte desejo de vingança, sentimento este muitas vezes transmitido de geração a geração. Na cultura timorense, perdoar não basta, é necessário muitas vezes um acerto de contas. Durante as narrações de conflitos históricos, os personagens de Cardoso aproveitavam a situação para realizar retaliações pessoais (FERREIRA, 2014, p. 215).

É o caso de Requiem para o navegador solitário. Sem incomodar um ou afetar diretamente outro, o governo salazarista percebe que Timor está numa posição vulnerável e, por isso, intensifica as investigações, através de Lavadinho. Há um fantasma da traição que ronda o território timorense, e os olhos, inevitavelmente, caem sobre Catarina. Segundo ela, os ocidentais, preocupados com as suas fronteiras na Europa, não tinham meios para socorrerem as suas colónias no oriente, que fatalmente cairiam uma atrás de outras como castelos de cartas. Inclusive Timor, pela sua situação estratégica, mesmo depois de o governo de Lisboa declarar a sua neutralidade perante o conflito. A invasão dos japoneses parecia estar iminente (CARDOSO, 2006, p. 151).

Catarina, assim como sua gata de jade que também é posta para chorar e ter seus cabelos penteados por Esmeralda, mostra assim mais uma de suas faces: de jovem menina viajante enviada por seu pai comerciante, passa a ser investigada de perto pela hostilidade dos representantes do poder salazarista, ao mesmo tempo que se enreda nas teias misteriosas de Malisera e sente o olhar de Indian Jones atravessar as paredes e desejar ter tudo o que Alberto Monteiro já teve. Não há limites para as possibilidades de expressão de Catarina, fato que enriquece o romance por mostrar uma figura com múltiplos e irredutíveis polos que se intercalam e sobrepõem nos momentos certos. Segundo Luiza Puntar Muniz Barreto, em Deslocamentos espaciais e identitários-afetivos dos sujeitos em trânsito (2015):

Podemos constatar [...] o descentramento do sujeito contemporâneo, que se apresenta cada vez mais plural, multifacetado e híbrido, sempre flutuando entre duas (ou mais) fronteiras, línguas, culturas e hábitos [...] Entre deslocamentos espaciais e identitário-afetivos, há sempre um sujeito, em maior ou menor grau, desajustado (BARRETO, 2015, p. 106).

A vida de Catarina em Timor é cantada. Uma canção sombria, harmoniosamente suave e aconchegante convida o leitor para um mergulho em águas noturnas. Ao adentrar na narrativa, sem cautelas, é-se envolto pela neblina dessa fascinante gata incrustada em Díli. Uma vez configurada como uma amante de aventuras nunca vividas, Catarina possui amor gratuito pelos desafios e vê no navegador, soldado único de uma guerra jamais travada, a imagem de uma vida emocionante e calorosa. Estar ao mar é estar 
livre? Como é deixar de crer no solo? Catarina observa o lado emocional do navegador:

Quando se fez marinheiro deixou o romantismo de lado. 0 mar passou a ser a sua profissão. A rotina fez da sua vida um tédio. Começou a ficar enjoado de andar tanto tempo embarcado. Só queria chegar a qualquer porto para se desforrar do tempo em que tinha ficado fechado numa gaiola de ferro (...) (CARDOSO, 2006, p. 153)

É só nos momentos finais da narrativa que a personagem, depois de perder os gatos, Esmeralda, filha de Madalena (que a essa altura já partira da ilha), e o navegador francês que, de fato, estava à deriva com sua poesia e sua coragem até atracar na praia graças à luz emitida pelo petromax da casa de Catarina, percebe que já realizara a viagem de que precisava. Certamente não foi como ela sonhara, mas, sem dúvidas foi o trajeto preciso para que notasse, enfim, sua liberdade. Diz a personagem: "Lembrei-lhe que o veleiro do navegador francês estava à sua disposição. Eu já tinha realizado a minha solitária travessia durante a guerra. Registei tudo no meu livro de bordo. Tencionava ficar em terra" (CARDOSO, 2006, p. 222).

Presa agora, unicamente, à responsabilidade de percorrer mares nunca dantes navegados reconhece que um navegador nada mais é do que um sobrevivente à condição primeira de ser exacerbadamente humano.

\section{Conclusão: um réquiem que nunca cessa de tocar}

O mar e os oceanos são elementos que suscitam histórias desde os primórdios da humanidade. Desde, no mínimo, os mitos que originaram a cultura ocidental, a imponência e os segredos marítimos vêm alimentando lendas, poesias e narrativas - para ficar apenas no campo da literatura que contribuem com a consolidação e renovação desse símbolo cultural. 0 mito de Prometeu pode ser relacionado às incursões marítimas: segundo a narrativa mítica, Prometeu pode representar o homem moderno que sofre a punição dos deuses por andar em um caminho por ele concebido. Ora, seria a ânsia heroica de descobrir o inóspito e conquistar o mundo o que pôs o ser humano na estrada de perdição? Seria uma condenação viver a soberba de atingir tudo aquilo que pela natureza foi inventado?

Seja sob o signo das águas em movimento, como mares, oceanos e rios, seja na fluidez natural desses elementos abundante na natureza terrestre, há de se pensar nos mares como elementos curativos. De acordo com Gaston Bachelard, em Á água e os sonhos (1998),

À água pura pedimos, pois, primitivamente, uma pureza ao mesmo tempo ativa e substancial. Pela purificação, participamos de uma força fecunda, renovadora, polivalente. A melhor prova desse poder íntimo é que ele pertence a cada gota do líquido. Inumeráveis são os textos em que a purificação aparece como simples aspersão (BACHELARD, 1998, p. 148).

A pureza pode ser um movimento involuntário, mas também uma ciência precisa. Catarina, protagonista do romance analisado, parece passar por um processo quase metamórfico em sua relação com o oceano: adquire coragem e embora respeite os mares, torna-se uma figura forte justamente por enfrentar os perigos de uma vida desolada e ilhada. Mas não há certezas que garantam a integridade da personagem em suas jornadas futuras, pois assim como o mar traz com as ondas, também pode afogar em repuxos. Ainda conforme Bachelard,

Sobre o tema dialético da pureza e da impureza da água, pode-se ver essa lei fundamental da imaginação material agir nos dois sentidos, o que constitui uma garantia do caráter eminentemente ativo da substância: uma gota de água pura basta para purificar um oceano; uma gota de água impura basta para macular um universo (BACHELARD, 1998, p. 149).

Dessa forma, ao utilizar um olhar de cunho antropológico-literário, essa pesquisa mostra que a metáfora da navegação e do mar como forma 
de liberdade e busca por sentido na vida ainda é muito forte no imaginário da literatura de língua portuguesa. A partir da personagem mencionada, essa pesquisa objetivou lançar um olhar sobre a metáfora da navegação, reconhecendo a importância histórica desse movimento de lançar-se ao mar e desbravar novas terras.

Profundas mudanças marcam a significação dos mares ao longo dos séculos. O que antes podia ser um infinito de medo e dúvidas que resguardava criaturas lendárias passa também a ser revestido de características positivas, para além das vantagens comerciais e políticas que envolvem a dominação de novas terras do além-mar. Conforme Antonio Carlos Diegues, em Ilhas e mares: simbolismo e imaginário (1998),

O banho de mar para efeitos terapêuticos popularizou-se no fim do século XVIII. As paisagens marítimas e costeiras, com seus barcos e pescadores passaram a ser também objetos de interesse. A mudança de visão em relação ao mar se deve também, nesse século, às viagens pitorescas da classe média em busca do exótico e do prazeroso e quase todos os escritores dessa época deixaram suas impressões sobre as viagens marítimas de recreação (DIEGUES, 1998, p. 203).

A relação do ser humano com os mares ultrapassa as noções de exploração e demonstração de coragem. Para a literatura lusófona, pode-se pensar em Raul Brandão, na obra Os pescadores (1923), que marca uma renovação na forma de se perceber essa relação: a maritimidade é uma característica quase inata das personagens narradas, e a pesca e demais funções que permitem a sobrevivência do povoado, uma natural dependência. É uma relação semelhante que Catarina estabelece em Requiem para o navegador solitário: a dependência de ser violentamente livre torna-a uma náufraga em situação de diáspora - embora em solo firme, a personagem só encontrará paz quando compreender que um lar é uma construção subjetiva que ela deve realizar sozinha.
As relações de poder com jogos políticos também fazem parte da cena literária: Timor é um dos países mais jovens do mundo - colônia portuguesa desde o século XVI - tendo sido sua independência declarada em 1975. No romance, a condição de uma Portugal salazarista é um grito de violência que se insurge contra a utópica condição de neutralidade desse território asiático em relação à Segunda Grande Guerra.

Com a dissolução da hegemonia de um centro único de onde ecoa todo o referencial cultural do mundo, a figura do navegador pode ser compreendida como uma das primeiras e mais satisfatórias tentativas de realizar conexões a níveis globais. $O$ que hoje é comum graças aos avanços tecnológicos, como a internet, foi primeiramente experenciado pelo contato humano que pode alcançar novos territórios nunca explorados. E ainda há diversas geografias das quais pouco ou nada o ser humano conhece.

Antonio Quadro Escuro, mais conhecido como Antero Escuro das Quadras Ainda Mais Escuras, personagem do romance, entoa versos que representam a voz do povo. Seja ao dizer "Marinheiro de Portugal, Nona manis de Batávia, Bolachas de água e sal, Tão nova e muito sábia" recheado de ironia ao analisar a relação de Catarina com o capitão do porto da ilha, ou ainda denotando sarcasmo quanto à espera de Catarina por um navegador que a resgate: "Catarina a Grande..., Antero o Pequeno, Quando for grande, Quero ser solitário". (Segundo Catarina, ele não escreveu navegador porque tinha medo do mar). Ou seja: a opinião da sociedade quanto à hostilidade eminente do clima pré-Guerra, das relações frágeis e das decisões políticas questionáveis está retratada num coro de um só homem.

É válido ressaltar que a abordagem da crítica, no entanto, à literatura timorense tem sido tímida. Claro, pode-se compreender tal fato devido ao caráter recente da emergência da literatura do Timor. A constituição do campo literário de um país deve-se a diversos fatores, dentre eles questões históricas, sociais e culturais. Não é o objetivo deste trabalho desvelar tais 
aspectos, contudo considera-se imprescindível que a questão seja levantada para futuro desenvolvimento. Cabe, por fim, destacar que, mesmo em pouca quantidade, existem outras dissertações, artigos e teses sobre a literatura de Luís Cardoso, diferentes dos observados ao longo deste trabalho, e que podem interessar aos estudiosos e pesquisadores das literaturas timorenses.

Por fim, observou-se que a investida de Catarina rumo a um novo território não se deu simplesmente para encontrar um marido digno dos seus juvenis sonhos de donzela. Pode-se compreender que o desejo da personagem era ser notada e sentida como uma criatura capaz de demonstrar força, afeto e compaixão, mas, acima de tudo, navegar, navegar e navegar. Como nas palavras de Miguel Torga, em (Súplica ${ }^{5}$ ):

Agora que o silêncio é um mar sem ondas

E que nele posso navegar sem rumo,

Não respondas

Às urgentes perguntas

Que te fiz.

Deixa-me ser feliz

Assim

Já tão longe de ti como de mim.

\section{Referências}

ALBUQUERQUE, Pedro Gabriel Reis. Caleidoscópio literário: a representação romanesca em Luís Cardoso. 2014. 152f. Dissertação (Mestrado) - Universidade Aberta, Lisboa, 2014.

ALMEIDA, Claudio. Representações do deslocamento no texto literário, Itinerários, Araraquara, n. 32, p.111-125, jan./jun. 2011.

BACHELARD, Gaston. A água e os sonhos: ensaio sobre a imaginação da matéria. São Paulo: Martins Fontes, 1998.

5 Texto presente em Câmara Ardente, Coimbra, 1962.
BARBOSA, Damares. Requiem para o navegador solitário, de Luís Cardoso. Resenha publicada na Revista Crioula, n. 8, nov. 2010.

BARRETO, Luiza Puntar Muniz. Deslocamentos espaciais e identitários-afetivos dos sujeitos em trânsit. Revista LitCult, v. 9, 2oㅗ. 2015.

CAMÕES, Luís. Os lusíadas: edição antológica, comentada e comparada com Ilíada, Odisseia e Eneida por Hennio Morgan Birchal. São Paulo: Landy, 2005.

CARDOSO, Luís. Requiem para o navegador solitário. Lisboa: Dom Quixote, 2006.

CARDOSO, Sérgio. O olhar do viajante (do etnólogo). In: NOVAES, A. (Org.). O olhar. 5. ed. São Paulo: Companhia das Letras, 1988.

COSTA, Letícia Vilella Lima da. Metáforas do mosaico: Timor Leste em Ruy Cinatti e Luís Cardoso. 2012. 170f. Tese (Doutorado) - Universidade de São Paulo, São Paulo, 2012. DIEGUES, Antonio Carlos. Ilhas e mares: simbolismo e imaginário. Hucitec, 1998.

DUTRA, Diego Pimentel de Souza. A cultura dos descobrimentos em Portugal: um estudo da relação entre a Sabedoria do Mar e o Conhecimento Acadêmico na Renascença. 2013. 122f. Dissertação (Mestrado) - Universidade Federal Fluminense, Niterói, 2013.

FERREIRA, Priscilla de Oliveira. Que Timor é este na literatura de Luís Cardoso? 2014 245f. Tese (Doutorado) - Universidade Federal do Rio Grande do Sul, Porto Alegre, 2014.

IANNI, Octavio. A metáfora da viagem. In: Enigmas da modernidade-mundo. Rio de Janeiro: Civilização Brasileira, 2000.

LIMA, Carlos Henrique Lucas. A questão transcontinental em Requiem para o navegador solitário. Revista desenredos, ano IV, n. 14, Teresina, 2012.

LISBOA, Adriana. Rakushisha. Ed. Alfaguara, Rocco, 2007.

MAFFESOLI, Michel. O imaginário é uma realidade. Revista FAMECOS, n. 15, 2001.

MEDEIROS, Aldinida. Travessias pela literatura portuguesa estudos críticos de Saramago a Vieira. Campina Grande: Eduepb, 2013

MELO NETO, João Cabral de. Obra completa. Rio de Janeiro: Nova Aguilar, 1994.

NETO, Leandro Carvalho Dascena. Expansão marítima portuguesa. Disponível em: <http://historiadomundo.uol.com.br/idade-moderna/expansao-maritima-portuguesa. htm>. Acesso em: 10 nov. 2017

PAULINO, Vicente; QUEIROGA, Mariene de Fátima Cordeio. A memória da infância e a formação da nação emergente em Luís Cardoso. Via atlântica, São Paulo, n. 31, p. $269-284,2017$ 
PEREIRA, Claudiany. Luís Cardoso e a vivência da diáspora: nota sobre a literatura de Timor Leste. Revista Língua e Literatura, Frederico Westphalen, v. 8, n. 12, p. 37-48, 2006.

RAMON, Micaela. Contributos para a constituição de um cânone lusófono: Timor-Leste no contexto da produção literária em língua portuguesa. Interfaces da lusofonia, Centro de estudos de comunicação e sociedade, Braga, Universidade do Minho. Disponível em: <http://www.lasics.uminho.pt/ojs/index.php/cecs_ebooks/article/view/1741/1673>. Acesso em: 08 ago. 2018

RAMOS, Fábio Pestana. O apogeu e declínio do ciclo das especiarias: uma análise comparativa das navegações portuguesas da Carreira da Índia e da Carreira do Brasil. 2002. 718f. Tese (Doutorado) - Universidade de São Paulo, São Paulo, 2002.

TORGA, Miguel. Câmara ardente. Coimbra: Coimbra Editora, 1962.

Recebido em 29/06/2018.

Aceito em 07/09/2018. 